\title{
THE UTILIZATION OF COMMON PROPERTY RESOURCES AND SUSTAINABLE MANAGEMENT: A CASE STUDY OF DOBHAN VDC OF PALPA
}

\begin{abstract}
Shiva Lal Bhushal
\section{ABSTRACT}

Traditional western economic approaches recognize and focus only two types of property, public and individual. But there is third dimension of property as common property resources (CPRs), which have been traditionally recognized by the society in Nepal. They are playing a crucial role in people's survival and community development particularly in rural Nepal. The common property resources can be recognized in two types viz, Natural property and Men made property. The nature and types of these properties vary from place to place and from one community to another. Each community has its own tradition and practices in utilization and management of CPRs based on their indigenous knowledge. The models for the utilization and management of these resources may vary from community to community. The concept of CPRs user group is showing the best way of resource management in study area as well as Nepalese society which can fit well into increasingly emphasized grass root level for democratic decision-making, participatory development and fair equity distribution. This study shows that each community can develop and have to develop its own model in keeping with the local socio-economic and resource related circumstances. In this context, this study tries to investigate some of the existing resources and their management practices in the study area for the sustainable use and community development with the help of CPRs and suggests that the groups can be facilitated by providing legal flexibility and logistic support from the government instead of imposing any outsider model.
\end{abstract}

\section{BACKGROUND}

Traditional theories of economic growth emphasize a better society with modern amenities where each individual enjoys qualitatively higher life with higher property and individual rights. Availability and exploitation of natural resources is considered as a major component of growth and development. These western approaches recognize only two types of property rights; state and private. These rights pertain to the permissible ownership and use of resources, goods and services. The ownership of an asset consists of rights to use of that asset; change is its form, substance and transfer of all rights through sale of ownership. Beyond government and private there exists a large area of human organizations and activity through which people collectively advance their wealth and well being. The contemporary theories and understanding of the world tend either to deny or ignore this fact.

Traditionally there is third type of property as common property resources (CPRs) and rights as well in Nepalese society. These common property

* Mr. Bhushal is Associate Professor in Economics at Butwal Multiple Campus, Butwal, Nepal. 


\section{THE UTILIZATION OF COMMON...}

rights are a bundle of entitlements defining both the rights and obligations in the use of CPRs. They include the rights of access to resources, the right to exclude other potential users, right to manage them and right to sell the resource base (Topal, et al. 2000). In rural environment of Nepal both ecological and socio economic sustainability is largely determined by the status of common property resources and rights. The usual CPRs are basically natural resources like water sources, forest sources, minerals and soils etc. Traditionally local water sources for drinking water and irrigation, forest sources for fuel, furniture, fodder and construction, local soil, sand and stones and minerals are used as CPRs by the local community.

Common property resources have great importance for the poor and women. Certain classes of common property resources are also among the degraded lands in Asia. Thus, they highlighted common causes of poverty and environmental deterioration (Smith \& Japal, 2000). CPRs continue to be an important part of community's natural resource endowment in LDCs. Despite their valuable contributions to people's sustenance, environmental stability and the strengthening of private resource based farming system, the researchers, policy makers and development thinkers have not shown adequate focus in this issue. Due to the virtual absence of political ideas about community organizations and actions for common benefit leaves an important area of human activity on comprehended, and planning alike disregard of CPRs and their productive potential is a major missing dimension of rural development strategies in developing countries and reflects much of the officialdom's indifference to environmental protection (Jodha, 1992)

In recent pasts, with the nationalization of forest management, Nepal has experienced extensive problems of environmental degradation as a result of heavy deforestation. This is leading to a process of degradation in both ecological and socio economic values. The development from western experiences of the economic growth model is found not suitable for the socio-cultural matrix of its traditional societies, especially with respect to the property rights of natural resources. It has been stressed several times: the growth elasticity of poverty varies widely across countries. Country comparisons imply that it is indispensable to pay close attention to the ability of poor and socially excluded groups and individuals to participate positively in the growth process. Participation depends on access and control over resources share of benefits education and other social relations technology and markets. The social relations and the resultant institutions that govern such access are of vital importance.

Common property resources are communal resources where all members of an identifiable community have some degree of property right and they can exclude outsiders, hold up these and regulate their use according to community need and agreement. The community and individuals traditionally had a stake in maintaining their community resource base for sustenance. Their stake is translated into effective management through knowledge and long experience they gained and transformed from generation to generation. The local resources control system, social sanctions to protect the community's stake and enforced mechanism worked effectively to protect the environment. However, resource 
TRIBHUVAN UNIVERSITY JOURNAL, VOL. XXVI, NO. 1, SEPT., 2009111

utilization and management strategies and practices may vary from community to community and the measure of how effectively and efficiently and community utilizes its CPRs typically reflected in how well that community manages and sustains its resources such that development processes are not impeded due to resource depletion and degradation.

The CPRs in Nepalese society generally are the natural resources and cultural heritages. In rural environment of Nepal both ecological and socioeconomic sustainability are largely determined by the status of CPRs available in the community. The socio-economic characteristics, community's capability, incentive and sense of ownership are important components of understanding the resources utilization and management. It is felt necessary to identify that, what are the CPRs available to the Nepalese society? How these resources are being utilized and managed for the well being of the community as a whole and the individual in particular? What are the constraints faced by the community for sustainability? The study therefore, attempts to explore the contribution and existing practices related to CPRs in the study area and discusses the factors behind both success and failures in the utilization and management of CPRs.

\section{THE CONCEPT OF COMMON PROPERTY RESOURCES}

The concept of common property resources is highly complex and controversial and has different meaning, scope and coverage according to several schools. But the most accepted concept is that the common property is a resource accessible to whole community to which no individual has exclusively property right and is owned and governed by an institution. A conceptually acceptable common division of resource is based on property right of private and public resources. The private resources are operationalised through institutional infrastructure such as court of law which prevents its unlawful use by the non owners, while public resource is generally managed by the institutions such as group, community or state, has free access to all, and its benefits are for the collective consumption of people. Singh (1994) is of the opinion that common property resources are owned in common by an identifiable group of people, regulated by social convention and legally enforceable rules.

Utilization and sustainable management of common property resources is very important issue as it ascertains its economic value and role in the maintenance of ecological balance. There are many modes of utilization of CPRs. Each and every community and society have its own experience and knowledge transferred by its old generation and corrected by successive new generations. Hence, many studies have been conducted in this respect. World Bank (1996) in its report has reviewed on utilization of common land resources. Many scholars have studied and suggested proper management practices at national and international scales.

This sustainability of resources use and sustainability of community can be conceptualized as follows: 


\section{THE UTILIZATION OF COMMON...}

Fig. 1: The process of sustainability of both resource use and community

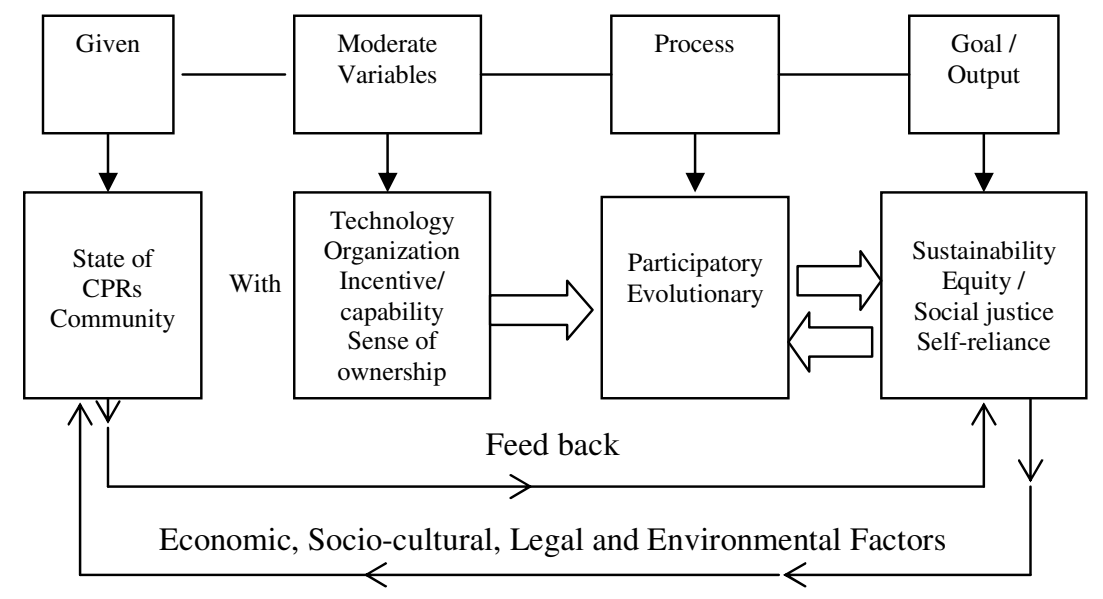

Community based resource management (CBRM) as a strategy for sustainable development: CBRM is conceived a process by which the people themselves are given the opportunity and responsibility to manage their resources, define their needs, goals and aspiration and make decisions affecting their well being. CBRM has gained popularity in the field of community forestry, irrigation and drinking water. In such management members of community do not think in terms of personal benefit, rather, they think interns of collective benefit. The sustainability of the community is largely determined by the state of CPRs with it. However, technological knowledge how to use available resources, organization and management capacity, sense of ownership and incentives largely moderate it. If the process is participatory and evolutionary, the goal of sustainability of CPRs as well as community will be achieved with equitable and justifiable utilization and self reliance of the community. The whole system is feedbacked by economic condition of the people, social structure and cultural values, legal provisions provided by the state and the environmental factors.

\section{METHODS AND MATERIALS}

Dobhan VDC of Plapa district is selected as the study area. The data and information are obtained from both primary and secondary sources. The primary data and evidences presented in this paper are based on the field study in the study area. Data collection was carried out through different methods that included structured survey, physical verification, recording of oral histories and focus group discussion with users. The focus of the study was on understanding the nature and status of CPRs and the practices made by the community for sustainability of resources and community itself.

Two groups with 5 members from user groups, teachers, members from user groups and local residents in two different settlements Jhumsa and Dobhan were conducted. The purpose was to collect information about contributions made by CPRs, existing practices to manage CPRs and measures taken for use 
regulations of CPRs. Similarly 30 simple respondents were purposively selected representing each forest user committee as well as belongs at least other user group like irrigation (pyne committee), drinking water, temple management committee, Kotghar, or such other simultaneously. Secondary sources are used to supplement the information gathered from primary sources.

\section{A BRIEF ACCOUNT OF INSTITUTIONAL DEVELOPMENT ON CPRS USE PRACTICES IN NEPAL}

Since time immemorial, the CPRs in Nepalese society has been managed by the local village heads together with community members. However the office of such heads was hereditary and thus, there may be possibilities to exploit the weaker section of the village community. This system was continued by 'Mukhia' Jimbwal (the village heads appointed by the government) till the Panchyat system has established. Sometime it was undertaken by the elected body of formal local institutions or communities themselves.

Over the past 50 years the forest cover has changed significantly in Nepal. A GIS analysis showed cycles of degradation followed by rehabilitation and then again degradation (Schreier, et.al, 2000). With the turning over the control of forest management to the communities has been claimed as a positive result for better management. There are so many causes which show that the intervention undertaken by the people themselves can be more effective and fruitful than those imposed by the state officials in CPRs management. Berkets et al. (1998) explain that the significance of CPRs is the established governance groups representing locally devised mechanisms to address problems of resource use, allocation and conflict. In Nepalese contest, CPRs is essential for two reasons. The nation is inneed on the path of decentralization and the process can only be moved forward by giving decision making authority to the grassroots level.

Traditionally it is practiced and believed that local people are the best managers of their common resources. In some community people have developed their own rules and regulations for managing and using their common resources to meet their day-to-day basic demands for fuel, fodder, grass, drinking water and irrigation keeping the idea of sustainability in mind. However, very limited research activities are found in this area. Basically rural villages in Nepal have experienced substantial change in management utilization of CPRs and environmental changes. It is necessary to bring out the impact of existing practices/management of CPRs on the socioeconomic conditions at village level implications. Do they have for the sustainability of village and communal life? This study concentrates on the experiences of Dobhan VDC which is of particular interest because local peoples have heavy dependence on CPRs for their livelihood. It is argued that the community of village level studies provide valuable extra microscopic insight into issues involved in utilization and sustainable management which may not be available from macro level research. But they should have to be interpreted with caution and one must be careful not to draw hasty generalizations from them. 
114 THE UTILIZATION OF COMMON...

\section{CONTRIBUTIONS MADE BY THE COMMON PROPERTY RESOURCES FOR VILLAGE ECONOMY}

The contributions made by the common property resources to the village people of the study area are presented in the table. This table was prepared with the help of group discussion arranged by the researcher. The participants were teachers, members of user groups and other peoples.

Table-1: Contribution of CPRs to Village Society

\begin{tabular}{|c|c|c|c|c|c|c|c|c|c|c|c|}
\hline S.N. & Types of Contribution & 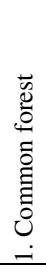 & 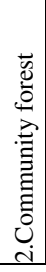 & 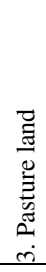 & 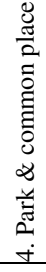 & 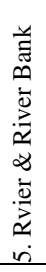 & 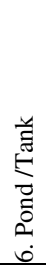 & 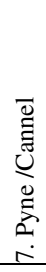 & 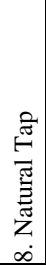 & 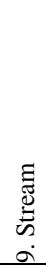 & 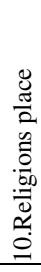 \\
\hline A. & \multicolumn{11}{|l|}{ Physical Product } \\
\hline 1 & Food/Fiber/Fuel & $\checkmark$ & $\checkmark$ & $\checkmark$ & & $\checkmark$ & & & & & \\
\hline 2 & Green glass/Fodder /Timber & $\checkmark$ & $\checkmark$ & $\checkmark$ & & $\checkmark$ & & & & & \\
\hline 3 & Animal Grazing & $\checkmark$ & $\checkmark$ & $\checkmark$ & & $\checkmark$ & & & & & \\
\hline 4 & Fruit \Vegetables & $\checkmark$ & $\checkmark$ & & & & & & & & \\
\hline 5 & Drought period substance & $\checkmark$ & $\checkmark$ & $\checkmark$ & & $\checkmark$ & & & & & \\
\hline 6 & Drinking water & & & & & $\checkmark$ & $\checkmark$ & & $\checkmark$ & $\checkmark$ & \\
\hline 7 & Irrigation & & & & & $\checkmark$ & & $\checkmark$ & & $\checkmark$ & \\
\hline 8 & Herbs/Medicinal uses & $\checkmark$ & $\checkmark$ & & & $\checkmark$ & & & & & \\
\hline 9 & Wild animals/Birds & $\checkmark$ & $\checkmark$ & $\checkmark$ & $\checkmark$ & & & & & & \\
\hline 10 & Sand/Stone/Slate/Mud & $\checkmark$ & $\checkmark$ & $\checkmark$ & $\checkmark$ & $\checkmark$ & & & & & \\
\hline 11 & Manure/Silt/Space & $\checkmark$ & $\checkmark$ & & & $\checkmark$ & & & & & \\
\hline B. & \multicolumn{11}{|l|}{ Source of income /Employment } \\
\hline 1 & Off seasonal income employment & $\checkmark$ & $\checkmark$ & $\checkmark$ & & $\checkmark$ & & & & & \\
\hline 2 & Additional crop activities & $\checkmark$ & $\checkmark$ & $\checkmark$ & & & & & & & \\
\hline 3 & Additional wild animal/Bird & $\checkmark$ & $\checkmark$ & $\checkmark$ & $\checkmark$ & $\checkmark$ & & & & & \\
\hline 4 & Patty trading & $\checkmark$ & $\checkmark$ & $\checkmark$ & & $\checkmark$ & & & & & \\
\hline 5 & Sustainability of poor & $\checkmark$ & $\checkmark$ & $\checkmark$ & & $\checkmark$ & & & & & \\
\hline C. & \multicolumn{11}{|l|}{ Social Cultural Gain } \\
\hline 1 & Park/Playground (Entertainment) & & & & $\checkmark$ & $\checkmark$ & & & & & \\
\hline 2 & Mental Relief & & & & & & & & & & \\
\hline D. & \multicolumn{11}{|l|}{ Environmental /Ecological Gain } \\
\hline 1 & Better Micro climate & $\checkmark$ & $\checkmark$ & $\checkmark$ & $\checkmark$ & $\checkmark$ & & & & & \\
\hline 2 & Sustainability of farming & $\checkmark$ & $\checkmark$ & & & $\checkmark$ & & $\checkmark$ & & $\checkmark$ & \\
\hline 3 & Resources \& Diversity Conservation & $\checkmark$ & $\checkmark$ & $\checkmark$ & & $\checkmark$ & & & & & \\
\hline
\end{tabular}

Source: Field survey data.

The table sketches the board picture of contributions made by various types of CPRs. They range from direct, visible contributions in terms of supplying physical items to less visible gains implied by the sustainability of agro-ecological system. 
TRIBHUVAN UNIVERSITY JOURNAL, VOL. XXVI, NO. 1, SEPT., 2009115

Because of monitoring and measurement complexities and lack of recording a complete quantification of the contributions made by CPRs is very different. The CPRs sources and contributions made by them to the village people are attempted to summarize in table. From the table we can summarize the following:

(i) The rural poor are more dependent in CPRs than rich. They receive the bulk of their food, fuel, , fodder and drought substance from CPRs. These are the main sources of income, employment and livelihood for the poor.

(ii) $\mathrm{CPR}$ product collection is an important source of income and employment during the periods when other opportunities are almost not existed.

(iii) CPRs provide the sources for water for irrigation, drinking water entertainment and such other for village people.

(iv) CPRs help for environmental and ecological balance.

(v) The inclusion of CPRs income in total household income from other sources help to reduce the income inequalities.

(vi) CPRs help for the betterment of other occupation such as live stock production crop and cash crop production petty trading.

(vii) CPRs are the main sources of construction of house and shade, furniture and such other.

(viii) CPRs construction utilization and management in these days helps to increase social cohesion.

\section{MANAGEMENT PRACTICES ON THE USE OF CPRS}

A detail ward-wise report, based on the discussion with the residents and member of user committee on the types of CPRs and their management practices is prepared. The summary is presented in the table 2 . The table indicates that user committees are formed basically on community forest, irrigation, drinking water and cultural heritage to regulate, upkeep and sustainability of the resources. The mode of cost and benefit sharing was found equal and proportional. No any barrier or protection was found for the use of CPRs from other members nearby. Traditionally the entrance in Kotghar and use of drinking water wells simultaneously with upper caste was prohibited for schedule caste but such traditions are not found in practice in these days. 
116 THE UTILIZATION OF COMMON...

Table-2: Ethnic Distribution, Types of CPRs and Management Practices

\begin{tabular}{|c|c|c|c|c|c|c|c|c|}
\hline & \multirow{2}{*}{$\begin{array}{c}\text { Village \& } \\
\text { Settlemmts }\end{array}$} & \multirow{2}{*}{$\begin{array}{c}\text { Main } \\
\text { cast } \\
\text { Groups }\end{array}$} & \multirow[t]{2}{*}{ CPRS Types } & \multicolumn{5}{|c|}{ Types of cost and benefit shearing } \\
\hline & & & & $\begin{array}{c}\text { Types of } \\
\text { benefit }\end{array}$ & $\begin{array}{l}\text { Mode of } \\
\text { Sharing }\end{array}$ & $\begin{array}{c}\text { Types of } \\
\text { Cast }\end{array}$ & $\begin{array}{c}\text { Mode of } \\
\text { Sharing }\end{array}$ & $\begin{array}{l}\text { Mgmt. } \\
\text { Practice }\end{array}$ \\
\hline \multirow[t]{3}{*}{1} & \multirow{3}{*}{$\begin{array}{l}\text { Jhumsa } \\
\text { Laudhawa } \\
\text { Gigintar }\end{array}$} & \multirow[t]{3}{*}{$\begin{array}{l}\text { Magar } \\
\text { Bramin }\end{array}$} & \multirow{3}{*}{$\begin{array}{l}\text { Common forest } \\
\text { Community } \\
\text { forest } \\
\text { River/Rivulent/ } \\
\text { Stream }\end{array}$} & $\begin{array}{l}\text { Grass fuel/ } \\
\text { food timber }\end{array}$ & Equal & No & - & \\
\hline & & & & $\begin{array}{l}\text { Grass fuel// } \\
\text { food timber }\end{array}$ & Equal & $\begin{array}{l}\text { Regulation/ } \\
\text { upkeep }\end{array}$ & equal & $\begin{array}{l}\text { User } \\
\text { committee }\end{array}$ \\
\hline & & & & Irrigation & Proportional & $\begin{array}{l}\text { Construction/ } \\
\text { Regulation }\end{array}$ & proportional &, \\
\hline & \multirow{5}{*}{$\begin{array}{l}\text { Jamure } \\
\text { Koili } \\
\text { Khola } \\
\text { Hattikot }\end{array}$} & \multirow{5}{*}{$\begin{array}{l}\text { Kami } \\
\text { Magar, } \\
\text { /Chhetri } \\
\text { Magar/ } \\
\text { Kami }\end{array}$} & \multirow{5}{*}{$\begin{array}{l}\text { Common } \\
\text { Forest } \\
\text { Community } \\
\text { Forest } \\
\text { River/Rivulet }\end{array}$} & Grazing/ grass & Equal & No & - & - \\
\hline \multirow{3}{*}{2} & & & & $\begin{array}{l}\text { Fuel/food } \\
\text { timber }\end{array}$ & Equal & $\begin{array}{l}\text { Regulation/ } \\
\text { Maintence }\end{array}$ & equal & $\begin{array}{l}\text { User } \\
\text { committee }\end{array}$ \\
\hline & & & & Grazing/grass & Proportional & $\begin{array}{l}\text { Construction/ } \\
\text { Maintence }\end{array}$ & proportional & " \\
\hline & & & & Fuelfood timber & Equal & No & - & - \\
\hline & & & & Irrigation & Equal & $\begin{array}{l}\text { Regulation// } \\
\text { Maintence }\end{array}$ & equal & $\begin{array}{l}\text { User } \\
\text { committee }\end{array}$ \\
\hline \multirow[t]{4}{*}{3} & \multirow{6}{*}{$\begin{array}{l}\text { Sisnari } \\
\text { Devithan } \\
\text { Badehre } \\
\text { Marabus }\end{array}$} & \multirow[t]{6}{*}{ Magar } & \multirow{6}{*}{$\begin{array}{l}\text { Common forest } \\
\text { Community } \\
\text { Forest } \\
\text { Pasture land } \\
\text { Stream }\end{array}$} & Grazing & Equal & No & - & - \\
\hline & & & & grass/fie/Timber & Equal & No & - & \\
\hline & & & & Grazing & Equal & No & - & \\
\hline & & & & $\begin{array}{l}\text { grass/fuel// } \\
\text { Timber }\end{array}$ & Equal & $\begin{array}{l}\text { Regulation/ } \\
\text { upkeep }\end{array}$ & proportional & $\begin{array}{l}\text { User } \\
\text { committee }\end{array}$ \\
\hline & & & & $\begin{array}{l}\text { Grazing grass/ } \\
\text { fuel Timber }\end{array}$ & Equal & No & - & - \\
\hline & & & & Drinking water & Equal & No & - & - \\
\hline \multirow[t]{3}{*}{4} & \multirow[t]{3}{*}{$\begin{array}{l}\text { Shreedada } \\
\text { Ranibas }\end{array}$} & \multirow[t]{3}{*}{$\begin{array}{l}\text { Magar } \\
\text { Magar }\end{array}$} & \multirow{3}{*}{$\begin{array}{l}\text { Common } \\
\text { Forest } \\
\text { Community } \\
\text { Forest } \\
\text { Rivulet }\end{array}$} & $\begin{array}{l}\text { Grazing/ } \\
\text { grass/ fuel } \\
\text { Timber }\end{array}$ & Equal & No & - & - \\
\hline & & & & $\begin{array}{l}\text { Grazing/ grass/ } \\
\text { fuel Timber }\end{array}$ & Equal & No & - & - \\
\hline & & & & Irrigation & Equal & No & - & - \\
\hline \multirow[t]{5}{*}{5} & \multirow{5}{*}{$\begin{array}{l}\text { Arghachap } \\
\text { Gadda } \\
\text { Bhutkhola } \\
\text { Basantapur }\end{array}$} & \multirow[t]{5}{*}{ Magar } & \multirow{5}{*}{$\begin{array}{l}\text { Common forest } \\
\text { Community } \\
\text { Forest } \\
\text { Shrubs land } \\
\text { Siddhababa/ } \\
\text { Rampithekus }\end{array}$} & $\begin{array}{l}\text { Grass/ fuel/ } \\
\text { Timber/ food }\end{array}$ & Equal & No & - & - \\
\hline & & & & $\begin{array}{l}\text { Grass/ fuel/ } \\
\text { Timber/ food }\end{array}$ & Equal & & + & - \\
\hline & & & & Grazing/ grass & Equal & No & - & - \\
\hline & & & & $\begin{array}{l}\text { Common } \\
\text { gathering }\end{array}$ & Equal & Regulation & proportional & - \\
\hline & & & & Worship & Equal & No & - & Mgmt. com \\
\hline 6 & $\begin{array}{l}\text { Bonee } \\
\text { gaun }\end{array}$ & $\begin{array}{l}\text { Magar } \\
\text { Magar }\end{array}$ & $\begin{array}{l}\text { Common forest } \\
\text { Community }\end{array}$ & $\begin{array}{l}\text { Grazing grass/ } \\
\text { fuel/ Timber }\end{array}$ & Equal & No & - & - \\
\hline & $\begin{array}{l}\text { Nayabazer } \\
\text { Salbus }\end{array}$ & Magar & $\begin{array}{l}\text { forest } \\
\text { Pasture land }\end{array}$ & $\begin{array}{l}\text { Grazing grass/ } \\
\text { fuel/ Timber }\end{array}$ & Equal & Regulation & proportional & $\begin{array}{l}\text { User } \\
\text { committee }\end{array}$ \\
\hline & & & Rivulet & $\begin{array}{l}\text { Grazing grass/ } \\
\text { fuel/ Timber }\end{array}$ & Equal & No & - & - \\
\hline & & & & $\begin{array}{l}\begin{array}{l}\text { Hydropower } \\
\text { irrigation }\end{array} \\
\end{array}$ & Proportional & Regulation & proportional & $\begin{array}{l}\text { User } \\
\text { committee }\end{array}$ \\
\hline 7 & $\begin{array}{l}\text { Thyangia } \\
\text { Hapur }\end{array}$ & $\begin{array}{l}\text { Magar } \\
\text { Chhetri }\end{array}$ & $\begin{array}{l}\text { Common forest } \\
\text { Community }\end{array}$ & $\begin{array}{l}\text { Grazing grass/ } \\
\text { fuel/ Timber }\end{array}$ & Equal & No & - & - \\
\hline & & & $\begin{array}{l}\text { forest } \\
\text { Pasture land }\end{array}$ & $\begin{array}{l}\text { Grazing grass/ } \\
\text { fuel/ Timber }\end{array}$ & Equal & No & - & - \\
\hline & Nuwakot & $\begin{array}{l}\text { Cheetri } \\
\text { Bramin/ }\end{array}$ & Rivulet & $\begin{array}{l}\text { Grazing grass/ } \\
\text { fuel/ Timber }\end{array}$ & Equal & No & - & - \\
\hline & & Kami & & $\begin{array}{l}\text { Irigation } \\
\text { Drinking water }\end{array}$ & Equal & No & & - \\
\hline 8 & Baroni & Magar & $\begin{array}{l}\text { Common forest } \\
\text { Community }\end{array}$ & $\begin{array}{l}\text { Grazing grass/ } \\
\text { fuel/ Timber }\end{array}$ & Equal & Regulation & proportional & $\begin{array}{l}\text { User } \\
\text { committee }\end{array}$ \\
\hline & & & $\begin{array}{l}\text { forest } \\
\text { Pasture land }\end{array}$ & $\begin{array}{l}\text { Grazing grass/ } \\
\text { fuel/ Timber }\end{array}$ & Equal & Regulation & Proportional & $\begin{array}{l}\text { User } \\
\text { committee }\end{array}$ \\
\hline & & & & Grazing & Equal & Regulation & - & - \\
\hline 9 & $\begin{array}{l}\text { Khursana } \\
\text { Dol }\end{array}$ & $\begin{array}{l}\text { Bramin } \\
\text { Kami }\end{array}$ & $\begin{array}{l}\text { Common forest } \\
\text { Community }\end{array}$ & $\begin{array}{l}\text { Grazing grass/ } \\
\text { fuel/ Timber }\end{array}$ & Equal & Regulation & - & - \\
\hline & $\begin{array}{l}\text { Paskinda } \\
\text { Suke Tal }\end{array}$ & $\begin{array}{l}\text { Magar } \\
\text { Bramin }\end{array}$ & $\begin{array}{l}\text { forest } \\
\text { Pasture land }\end{array}$ & $\begin{array}{l}\text { Grazing grass/ } \\
\text { fuel/ Timber }\end{array}$ & Equal & Regulation & - & - \\
\hline & & & $\begin{array}{l}\text { River bank } \\
\text { Lake }\end{array}$ & $\begin{array}{l}\text { Grazing grass/ } \\
\text { fuel/ Timber }\end{array}$ & Equal & Regulation & - & \\
\hline & & & & Irrigation & Proportional & $\begin{array}{l}\text { Regulation/ } \\
\text { development }\end{array}$ & - & \\
\hline & & & & Hydropower & Proportional & $\begin{array}{l}\text { Regulation/ } \\
\text { development }\end{array}$ & - & \\
\hline
\end{tabular}

Source: Field survey, 2065. 
Among the different types of CPRS, community forest user groups are found most successful in the management and upkeep of their resources. It was due to the sense of ownership and self sustain of resources need and the participatory process of management. The community management of forest has changed the concept of community life. Villagers start to think in terms of collective benefit rather than personal. All incomes earned from the community forest are spending in community development like village road, irrigation, school, drinking water, temple etc.

\section{MEASURES DIRECTED TO USES REGULATION OF CPRS}

Proper records of general cases are not found kept in the office or user committee. With the help of memory record of the officials and residences, some of the events and cases are recorded to get the message about uses regulation of CPRS in the study area during the study year. The summary information is presented in the table 3 .

Table-3: Measures directed to use regulation of CPRs.

\begin{tabular}{|c|c|c|}
\hline S.N. & Particulars & Frequencies \\
\hline 1. & Protest against illegal cutting tree & Frequently occurs \\
\hline 2. & $\begin{array}{l}\text { Blocking access to CPRS by } \\
\text { villagers }\end{array}$ & No records \\
\hline 3. & Village level meeting & 1-2 moth duration \\
\hline 4. & Penalty record for trespassers & Maximum Rs1000/ is recorded \\
\hline 5. & $\begin{array}{l}\text { Agreement on seasonal closure of } \\
\text { forest }\end{array}$ & Routinely \\
\hline 6. & $\begin{array}{l}\text { Plantation and transplantation of } \\
\text { tree }\end{array}$ & No record \\
\hline 7. & $\begin{array}{l}\text { Linking the CPRS protection and } \\
\text { conservation with the other } \\
\text { occasion. }\end{array}$ & School champions are done \\
\hline 8. & Maintaining village bulls & Generally I each community \\
\hline 9. & $\begin{array}{l}\text { Seeking logistic support from } \\
\text { government and other } \\
\text { organization }\end{array}$ & $\begin{array}{l}\text { Terai Arc land } \\
\text { (TAL)Development project is } \\
\text { involving }\end{array}$ \\
\hline 10. & $\begin{array}{l}\text { Litigation/factional fight on misuse } \\
\text { of CPRS }\end{array}$ & No record \\
\hline
\end{tabular}

Source: Field survey data:

\section{CAUSES AND PROCESS OF DEPLETION OF CPRS IN STUDY AREA}

The causes of CPRS decline are the human factors like socio-economic, legal, political and technical as well as environmental factors (natural factors). So the causes and process of CPRs decline in study area are summarized in the figure. The main causes of CPR decline are, summarized in main headings:

1. Increasing pressure on CPRs (due to population growth, poverty and marketing of CPRs. etc) 
2. Lack of participatory and inclusive management, ignoring traditional ways of protecting CPRs without replacing better ways, lack of sense of ownership, disregard of non money values of CPRs and effect of structural change etc.

3. Shrinkage of CPRs (due to illegal accessing of local leader or others, distribution of CPRs for the welfare purpose, sale or privatization of CPRs by government of local community and side effect of other development activities etc) and

4. Natural disaster and lose of ecological or other environmental balance. The tectonic instability as well as the relatively young age of mountains lends themselves to high natural erosion. we can further summarizes these factors in two headings as (i) Decline in quality of CPRs and (ii) Decline in quantity of CPRS both by human and non human factors.

\section{CAUSES AND PROCESS OF DEPLETION OF CPRS}

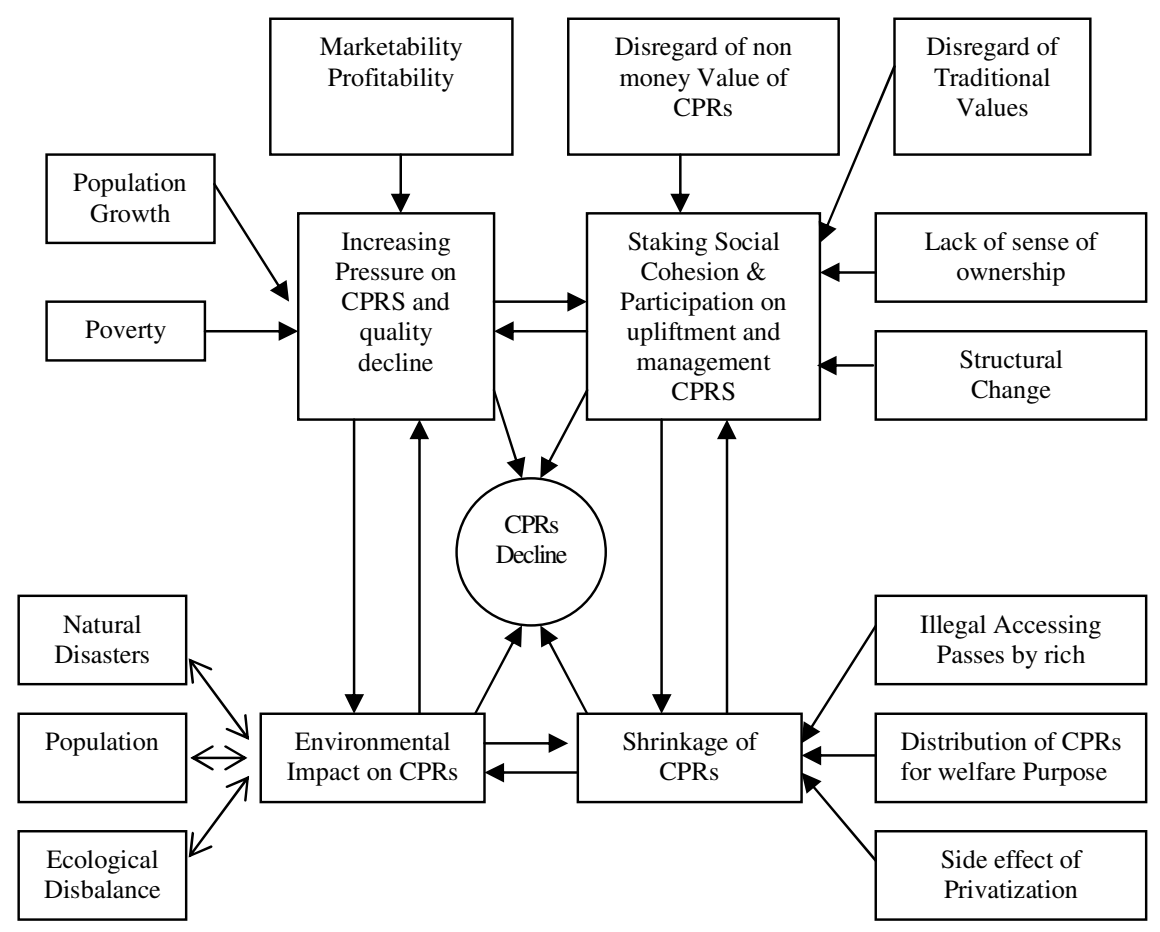

\section{CONCLUSION AND RECOMMENDATIONS}

In the rural society of Nepal like Dobhan VDC, both the ecological and socio economic sustainability is largely determined by the status of the common property resources (CPRs). The CPRs can be categorized into two types viz, natural property and man-made like socio-economic infrastructure and cultural heritages. The nature and type of common property resources vary from place to place and 
community to community. Each community has its own tradition and practices on utilization and management of CPRs based on their indigenous knowledge. There may not be unique models for their utilization and management.

The concept of CPR user group is showing the best way of resource management in study area. This can fit well into increasingly emphasized grass root level democratic system, participatory development and equity oriented distribution. But each community may have to develop a model in keeping with the local socio economic and resource related circumstances. Without imposing specific models state can facilitate this task by providing legal flexibility and logistic support.

Common land resources, water resources and cultural heritages are found the main CPRs available in their different form in the study area. They are providing a significant contribution in direct visible and invisible from such as physical product for direct consumption, as a source of income and employment, social, cultural gains and ecological balance. The communities in the study area have developed their own system of utilization and management of CPRs based on their indigenous knowledge, based on their circumstances and states legal and logistic supports. Some NGOs are found involved on the logistic and technological support to upkeep the CPRs and sustainability of community as well. The historical prospective and experience of the people in study area suggest that the users themselves are the best managers for their common resources.

The existing trend of urbanization and development in Nepal has been under estimate the vital role of CPRs which is one of the causes of CPRs decline at worst. The side effect of urban development, pressure of population growth, monetization of CPRs in market, illegal use and such are found main causes of CPRs depletion in the study area. The CPRs management practices in the study area show that the conservation of CPRs and their management in the small, flexible and user from participatory management can provide the models of an important development tool. The community based users managed CPRs can be the part of the development process, but a sufficient research and actions are needed to find out the forms of community organizations and legal and logistic support for such community based management.

\section{WORKS CITED}

Berkets, F., Davidson-Hunt, I \& Davidson-Hunt, K 1998. "Diversity of common property resources and diversity of social interests in the western Indian Himalaya." Mountain Research and development. 18(1):19:23.

Bhusal, S.L. 2004. Role of women as a farm manager, A case study of Dhakabang VDC. Mini-Research (unpublished), UGC, Nepal

Jalal, K.F. 2000. Sustainable Development in Asia. ADB Manila, Philippines.

Jodha, N.S. 1992. Common Property Resources: A missing Dimension of Development Strategies.

1997. Management of CPRs in selected Dry Area of India, in Kerr. J.M. et.al (eds.). "Natural Resources Economics: Theory and application in India." Economic and Political weekly. Vol. 27. 


\section{THE UTILIZATION OF COMMON...}

Scheier, H., Shrestha B., Brow S. \& Shah, P.B. 2000. "Forest Dynamics in Nepal: Quantity, Quantity and Community Forestry Issues in Middle Mountain Watersheds." The People and Resources Dynamics.

Seddon, D. 1987. Nepal: A State of Poverty. New Delhi, Vikas Publication.

Singh, K 1994. Managing Common pool resources. New Delhi: Oxford University Press.

Tisdell, C.A., Roy, K.C. \& Gannon. 1996. "Sustainability of Tribal villagers in west Bengal." Economic Development and Change, South Asia and Third World. edited by Ghosh et al., New Age international publishers.

Topal, S., Samal, P.K., Pant, P. \& Rawat, D.S. 1998. Socioeconomic and cultural adoptions in the central Himalaya. Man in India. 78 (1) 9-25.

World Bank. 1996. "Staff Appraisal Report." India economic development, project No. 1494. August, Washington D.C. 